\title{
Природопользование
}

DOI: 10.12737/article_5c1a321965cf38.69751554

УДК $630 * 266$

ФОРМИРОВАНИЕ ЗАЩИТНЫХ НАСАЖДЕНИЙ ИЗ ДУБА ЧЕРЕШЧАТОГО

В ЦЕНТРАЛЬНОМ ЧЕРНОЗЕМЬЕ РОССИИ

доктор сельскохозяйственных наук, доцент В. И. Михин ${ }^{1}$

кандидат сельскохозяйственных наук, доцент Е. А. Михина ${ }^{1}$

1 - ФГБОУ ВО «Воронежский государственный лесотехнический университет имени Г.Ф. Морозова»,

г. Воронеж, Российская Федерация

Лесомелиоративные комплексы, представленные защитными насаждениями различных категорий, в условиях Центрального Черноземья имеют сохранность по площади около 600 тыс. га, где в долевом участии линейные насаждения из дуба черешчатого занимают около 23 \%. Лесные полосы произрастают в различных почвенно-климатических условиях. Имеется большое разнообразие схем смешения, ширины лесополос, размещения посадочных мест. В ветроломных лесных полосах с участием дуба черешчатого в период 1988-2015 гг. установлено, что лучшие показатели роста в возрасте 32-40 лет главная порода имеет на чернозёме типичном и выщелоченном, чем в других почвенных условиях. В возрасте 32-45 лет различия в таксационных показателях дуба по высоте, диаметру и их приростам составляют около 20 \% в пользу насаждений с шириной междурядья 2.5 м по отношению к узким междурядьям (1.5 м). Оптимальным размещением посадочных мест для чистых по составу лесополос из дуба черешчатого является 2.5×0.7-1.0 м с густотой посадки 4.0-6.0 тыс. шт./га. Увеличение ширины насаждения с 15.0-20.0 м до 30.0 м приводит к снижению биометрических показателей роста дуба на 2.5-21.2 \%. В средневозрастных лесных полосах при совместном произрастании дуба черешчатого с сопутствующими породами он имеет больше высоту на $22 \%$, диаметр на 38 \% по отношению к насаждениям, где введены только кустарники. Наилучшая лесоводственно-мелиоративная оценка насаждений шириной 7.5-10.0 м, где используется порядное смешение дуба с сопутствующими породами (клён остролистный, липа мелколистная). При выращивании дуба черешчатого в коридорах из быстрорастущих пород ширина междурядий принимается 2.5-3.0 м, отделяются ряды главной породы от быстрорастущей рядами сопугствующих пород.

Ключевые слова: защитные насаждения, дуб черешчатый, биометрические показатели, рост, формирование.

\section{FORMATION OF ENGLISH OAK PROTECTIVE PLANTS IN THE CENTRAL CHERNOZEM REGION} OF RUSSIA

\author{
DSc in Agriculture, Associate Professor V. I. Mikhin ${ }^{1}$ \\ $\mathrm{PhD}$ in Agriculture, Associate Professor E. A. Mikhina ${ }^{1}$ \\ 1 - Federal State Budget Education Institution of Higher Education «Voronezh State University of Forestry \\ and Technologies named after G.F. Morozov», Voronezh, Russian Federation
}

\begin{abstract}
Forest melioration complexes, represented by protective plantings of various categories, in the conditions of the Central Chernozem region are preserved over an area of about 600 thousand hectares, where linear plantings of English oak occupy about $23 \%$ in the shared participation. Forest belts grow in different soil and climatic conditions. There is a wide variety of blending patterns, width of forest belts, seating locations. It is established that the main variety has better indicators of growth at the age of 32-40 years on common black soil than in other soil conditions in windbreak forest belts with English oak in the period 19882015. At the age of 32-45 years, the differences in tax rates of oak in height, diameter and their increments are about $20 \%$ in favor of plantations with $2.5 \mathrm{~m}$ spacing between narrow aisles $(1.5 \mathrm{~m})$. The optimal planting points for pure English oak forest belts is $2.5 \times 0.7-1.0 \mathrm{~m}$ with a planting density of 4.0-6.0 thousand $\mathrm{pcs} / \mathrm{ha}$. An increase in the planting width from 15.0-20.0 $\mathrm{m}$ to $30.0 \mathrm{~m}$ leads to a decrease in the biometric indicators of oak growth by $2.5-21.2 \%$. In middle-aged forest belts, with common growth of English oak with accompanying species, it has a greater height by $22 \%$, a diameter by $38 \%$ in relation to plantations, where only shrubs are introduced. The best silvicultural and ameliorative assessment is given to plantations with $7.5-10.0 \mathrm{~m}$
\end{abstract}




\section{Природопользование}

width, where good mixing of oak with accompanying species is used (Norway maple, little-leaved linden tree). When growing English oak in the corridors of fast-growing species, the width of the rows between rows is 2.5-3.0 m, the main species rows are separated from the fast-growing rows of accompanying species

Keywords: protective stands, English oak, biometric indicators, growth, formation.

\section{Введение}

Длительное произрастание защитных лесных насаждений способствует формированию экологического каркаса [1]. При создании искусственных ландшафтов необходимо учитывать растительные сообщества территорий $[8,9,10]$. Площадь сохранившихся лесных полос различных категорий в Центральном Черноземье составляет около 600 тыс. га.

Дуб черешчатый благодаря целому ряду биологических особенностей и хозяйственно ценных признаков получил широкое распространение в защитных насаждениях лесостепи и степи. Имеет глубокую корневую систему, ветроустойчив, долговечен, зимостоек, засухоустойчив и в лучших лесорастительных условиях достигает высоты до 40 м. Интенсивно выделяет кислород, переносит повышенную концентрацию соли и сухость почвы, светолюбив. В молодости энергия его роста невысока, и только после 5 лет он усиливает рост в высоту, в оптимальных условиях прирост может достигать 1,0-1,5 м в год. К почве малотребователен, однако лучшие показатели имеет на влажных чернозёмах и тёмно-серых лесных почвах [2, 5, 7].

\section{Методы исследования и объекты}

В искусственных линейных насаждениях с участием дуба черешчатого в период 1988-2015 гг. выполнялось изучение биометрических показателей роста в зависимости от состава, ширины лесополос, агротехнических и лесокультурных приёмов их создания [4]. Пробные участки закладывались в различных почвенных условиях с количеством деревьев изучаемых видов не менее 200 шт.[6]. Для анализа хода роста выбирали среднее модельное дерево. Экспериментальные данные обрабатывались математико-статистическими методами [3]. Объектами изучения послужили полезащитные ветроломные насаждения в условиях лесостепи и степи Центрального Черноземья России.

\section{Результаты}

Защитные насаждения с участием дуба черешчатого (Qercus robur L.) произрастают на чернозёме типичном, выщелоченном, обыкновенным, солонцеватых, серых и тёмно-серых лесных почвах в условиях Д2 и занимают площадь около 23 \% от площади всех лесомелиоративных объектов. При этом имеет место большое разнообразие схем смешения, ширины лесополос, размещение посадочных мест.

Показатели роста дуба зависят от плодородия почв. Анализ табл. 1 показывает, что на чернозёме типичном и выщелоченном они выше, чем в других почвенных условиях (возраст 33-35 лет).

Аналогичные закономерности сохраняются и в возрасте 32-40 лет, при этом возраст насаждений на пробной площади 108 (серая лесная почва) выше, чем на пробных площадях 69 и 76 (чернозем типичный и выщелоченный). Существенность различия имеет место при достаточно высокой точности исследования.

Анализ данных хода роста дуба черешчатого по высоте в зависимости от почвенных условий подтверждает сделанный ранее вывод (табл. 2).

Наиболее высокие показатели дуб черешчатый имеет на чернозёме типичном и тёмно-серой лесной почве, самые низкие - на почвах овражно-балочного комплекса. Так, в возрасте 20 лет высота дуба на чернозёме типичном в 1,2 раза выше, чем на тёмно-серой лесной почве; в 1,3 раза выше, чем на чернозёме обыкновенном; в 1,4 раза выше, чем на чернозёме выщелоченном; в 1,4 раза выше, чем на серой лесной почве; в 2,4 раза выше, чем на почвах овражно-балочного комплекса.

Успешность роста дуба черешчатого в защитных насаждениях предопределяется также первоначальной густотой посадки, которая, в свою очередь, зависит от размещения посадочных мест растений между рядами и в рядах (табл. 3). Пробные площади 69 и 71 заложены в полезащитных лесополосах на чернозёме типичном среднегумусном тяжелосуглинистом, возраст 38-39 лет. Главная порода - дуб черешчатый, сопутствующие: клён татарский, берёза повислая, ясень зелёный и другие. На пробной площади 69 таксационные показатели выше, чем на пробной площади 71, где густота посадки меньше, чем на предыдущей.

Пробная площадь 54 заложена в прибалочной лесополосе на чернозёме выщелоченном среднегу- 


\section{Природопользование}

Таблица 1

Биометрический потенциал дуба черешчатого на разных почвах

\begin{tabular}{|c|c|c|c|c|c|c|}
\hline $\begin{array}{l}\text { № пр. } \\
\text { пл. }\end{array}$ & Тип почвы & Размещение посадочных мест, м & $\begin{array}{l}\text { Возраст, } \\
\text { лет }\end{array}$ & $\begin{array}{c}\text { Диа- } \\
\text { метр, м }\end{array}$ & Высота, м & Бонитет \\
\hline 68 & $\begin{array}{c}\text { Чернозём } \\
\text { выщелоченный }\end{array}$ & $\begin{array}{c}5,0 \text { x 3,0 } \\
\text { (посев квадратно-гнездовой) }\end{array}$ & 33 & $\begin{array}{c}12,9 \pm \\
0,5\end{array}$ & $8,2 \pm 0,6$ & Ш \\
\hline 93 & $\begin{array}{l}\text { Чернозем } \\
\text { типичный }\end{array}$ & $\begin{array}{c}5,0 \text { x 3,0 } \\
\text { (посев квадратно-гнездовой) }\end{array}$ & 33 & $\begin{array}{c}13,2 \pm \\
0,3\end{array}$ & $10,2 \pm 0,3$ & $\Pi$ \\
\hline 120 & $\begin{array}{l}\text { Чернозем } \\
\text { типичный }\end{array}$ & $\begin{array}{c}5,0 \text { x 3,0 } \\
\text { (посев квадратно-гнездовой) }\end{array}$ & 35 & $\begin{array}{c}15,4 \pm \\
0,4\end{array}$ & $12,2 \pm 0,2$ & $\Pi$ \\
\hline 109 & $\begin{array}{c}\text { Серая лесная } \\
\text { почва }\end{array}$ & $\begin{array}{c}5,0 \text { x 3,0 } \\
\text { (посев квадратно-гнездовой) }\end{array}$ & 34 & $\begin{array}{c}10,4 \pm \\
0,2\end{array}$ & $8,0 \pm 0,1$ & Ш \\
\hline 96 & $\begin{array}{l}\text { Чернозем } \\
\text { типичный }\end{array}$ & $1,5 \times 0,7$ & 41 & $16,5 \pm 0,4$ & $14,5 \pm 0,2$ & $\Pi$ \\
\hline 69 & $\begin{array}{l}\text { Чернозем } \\
\text { типичный }\end{array}$ & $1,5 \times 0,7$ & 39 & $14,0 \pm 0,5$ & $12,1 \pm 0,5$ & Ш \\
\hline 76 & $\begin{array}{c}\text { Чернозём } \\
\text { выщелоченный }\end{array}$ & $1,5 \times 0,7$ & 39 & $14,1 \pm 0,4$ & $12,0 \pm 0,5$ & Ш \\
\hline 108 & $\begin{array}{c}\text { Серая лесная } \\
\text { почва }\end{array}$ & $1,5 \times 0,7$ & 40 & $10,5 \pm 0,3$ & $10,2 \pm 0,3$ & Ш \\
\hline
\end{tabular}

Таблица 2

Рост дуба черешчатого по высоте (м) в зависимости от типов почвенных условий

\begin{tabular}{|c|c|c|c|c|c|c|}
\hline $\begin{array}{c}\text { Возраст, } \\
\text { лет }\end{array}$ & $\begin{array}{c}\text { Чернозём } \\
\text { типичный }\end{array}$ & $\begin{array}{c}\text { Тёмно-серая } \\
\text { лесная почва }\end{array}$ & $\begin{array}{c}\text { Чернозём } \\
\text { обыкновен- } \\
\text { ный }\end{array}$ & $\begin{array}{c}\text { Чернозём } \\
\text { выщелочен- } \\
\text { ный }\end{array}$ & $\begin{array}{c}\text { Серая лес- } \\
\text { ная почва }\end{array}$ & $\begin{array}{c}\text { Почвы овражно- } \\
\text { балочного } \\
\text { комплекса }\end{array}$ \\
\hline 2 & 0,5 & - & 0,4 & - & 0,3 & 0,2 \\
\hline 4 & 1,4 & 1,7 & 1,4 & 0,9 & 0,9 & 0,7 \\
\hline 6 & 2,7 & 3,0 & 1,7 & 1,7 & 1,7 & 2,2 \\
\hline 8 & 4,0 & 4,2 & 2,6 & 2,3 & 2,5 & 2,2 \\
\hline 10 & 5,1 & 5,3 & 3,3 & 2,9 & 3,2 & 2,5 \\
\hline 12 & 6,4 & 6,0 & 4,3 & 4,6 & 5,2 & 3,3 \\
\hline 14 & 7,1 & 6,7 & 5,0 & 5,5 & 6,3 & 3,6 \\
\hline 16 & 8,8 & 7,4 & 6,1 & 6,2 & 6,7 & 3,8 \\
\hline 18 & 9,9 & 8,2 & 7,3 & 6,9 & 7,2 & 4,4 \\
\hline 20 & 10,7 & 9,0 & 8,2 & 7,9 & 7,8 & - \\
\hline 22 & 11,6 & 10,3 & 8,8 & 8,4 & - & - \\
\hline 24 & 12,4 & 11,4 & 10,0 & 8,9 & - & - \\
\hline 26 & - & 12,0 & 10,8 & - & - & - \\
\hline 30 & - & 12,8 & 11,7 & - & - & - \\
\hline
\end{tabular}

мусном среднемощном. Даже в возрасте 29 лет на слабосмытой почве дуб черешчатый произрастает по II классу бонитета, что связано с более редким размещением посадочных мест $(2,5 \times 0,7$ м). Средний диаметр на этой пробной площади ниже, чем на предыдущей (пр. пл. 71). Однако средняя высота на 1,7 м выше.
Следовательно, размещение посадочных мест 2,5 × 0,7 м является более оптимальным, чем на двух других пробных площадях (пр. пл. 69,71).

Аналогичные закономерности имеют место при сравнении показателей роста дуба черешчатого в лесополосах с различной густотой посадки и другими воз- 
Таблица 3

Рост дуба черешчатого в зависимости от густоты посадки и размещения посадочных мест

\begin{tabular}{|c|c|c|c|c|c|c|}
\hline $\begin{array}{c}\text { № } \\
\text { пр. пл. }\end{array}$ & Тип почвы & $\begin{array}{c}\text { Возраст, } \\
\text { лет }\end{array}$ & $\begin{array}{c}\text { Густота посадки, } \\
\text { шт./га, размещение, м }\end{array}$ & Диаметр, см & Высота, м & Бонитет \\
\hline 69 & Чернозём типичный & 39 & $\begin{array}{c}9523 \\
(1,5 \times 0,7)\end{array}$ & 14,0 & 12,1 & Ш \\
\hline 71 & Чернозём типичный & 38 & $\begin{array}{c}10000 \\
(1,0 \times 1,0)\end{array}$ & 11,3 & 8,3 & $1 \mathrm{~V}$ \\
\hline 54 & $\begin{array}{c}\text { Чернозём выщело- } \\
\text { ченный }\end{array}$ & 29 & $\begin{array}{c}5714 \\
(2,5 \times 0,7)\end{array}$ & 6,5 & 10,0 & $\Pi$ \\
\hline 132 & $\begin{array}{c}\text { Почвы овражно- } \\
\text { балочного комплекса }\end{array}$ & 15 & $\begin{array}{c}8000 \\
(2,5 \times 0,5)\end{array}$ & 5,4 & 6,6 & $\Pi$ \\
\hline 133 & $\begin{array}{c}\text { Почвы овражно- } \\
\text { балочного комплекса }\end{array}$ & 15 & $\begin{array}{c}5714 \\
(2,5 \times 0,7)\end{array}$ & 7,2 & 6,0 & 1 \\
\hline 175 & Серая лесная почва & 90 & $\begin{array}{c}6667 \\
(1,5 \times 1,0)\end{array}$ & 38,4 & 19,3 & $\Pi$ \\
\hline 176 & Серая лесная почва & 90 & $\begin{array}{c}4444 \\
(1,5 \times 1,5)\end{array}$ & 36,7 & 21,8 & $1 \mathrm{a}$ \\
\hline 235 & $\begin{array}{c}\text { Чернозём } \\
\text { обыкновенный }\end{array}$ & 31 & $\begin{array}{c}3330 \\
(5 \times 3)\end{array}$ & 28,1 & 13,3 & 1 \\
\hline 266 & $\begin{array}{c}\text { Чернозём } \\
\text { обыкновенный }\end{array}$ & 31 & $\begin{array}{c}6667 \\
(1,5 \times 1,0)\end{array}$ & 18,9 & 11,3 & $\Pi$ \\
\hline
\end{tabular}

растами (пр. пл. 132, 133, 175, 176, 235, 266). Так, оптимальным размещением посадочных мест в чистых по составу лесополосах из дуба черешчатого является $2,5 \times 0,7-1,0$ м с густотой посадки 4,0-6,0 тыс. растений на 1 га. При таком размещении обеспечивается механизированный уход за почвой между рядами до периода смыкания, создаются оптимальные условия для почвенного питания растений и обеспечения их влагой.

Ширина лесополосы и число рядов в ней оказывают влияние на показатели роста и развития дуба. При выборе ширины необходимо учитывать, что чем выше этот показатель, тем больше пашни отводится под создание защитных насаждений. Исходя из необходимости экономии пахотных угодий, ширина лесополос должна быть такой, которая способствовала бы формированию в ней оптимальной структуры и обеспечивала высокую эффективность защитного лесоразведения. Сравнение биометрических показателей роста дуба, полученных в двух насаждениях, произрастающих в одинаковых условиях (чернозём типичный, среднегумусный, среднемощный, тяжелосуглинистый), показывает, что в лесополосе шириной 20 м они не- сколько ниже (на 2,3-19,6 \%), чем шириной 15 м (пр. пл. 68,93$)$. Это связано с оптимальными условиями освещенности в узких насаждениях с меньшим количеством рядов.

Данная закономерность прослеживается также в лесополосе (пр. пл. 109), состоящей из 6 рядов шириной 30,0 м, созданной квадратногнездовым посевом. Биометрические показатели роста в таких насаждениях на 2,5- 21,2 \% ниже, чем в лесополосах шириной $15,0-20,0$ м. При этом условия роста и развития древесных пород одинаковы, но более успешно по высоте и диаметру дуб черешчатый произрастает в насаждениях шириной 15,0 м (табл. 4). Различия по высоте и диаметру являются достоверными.

Таким образом, как с биологической, так и с агроэкономической точек зрения оптимальными являются узкие полосы шириной не более 15,0 м.

В защитных насаждениях на землях сельскохозяйственных предприятий ЦЧР применялись различные методы создания (посев квадратногнездовой, посадка рядовая). Чистые лесополосы из дуба создавались квадратно-гнездовым посевом и 


\section{Природопользование}

Таблица 4

Рост дуба черешчатого в лесных полосах различной ширины

\begin{tabular}{|c|c|c|c|c|c|c|c|}
\hline $\begin{array}{c}\text { № пр. } \\
\text { пл. }\end{array}$ & Тип почвы & $\begin{array}{c}\text { Воз- } \\
\text { раст, } \\
\text { лет }\end{array}$ & $\begin{array}{c}\text { Ширина, } \\
\text { м }\end{array}$ & $\begin{array}{c}\text { Размещение } \\
\text { посадочных } \\
\text { мест, м }\end{array}$ & $\begin{array}{c}\text { Диаметр, } \\
\text { см }\end{array}$ & Высота, м & $\begin{array}{c}\text { Бони- } \\
\text { тет }\end{array}$ \\
\hline 68 & Чернозем типичный & 33 & 20 & $5,0 \times 3,0$ & $12,9 \pm 0,5$ & $8,2 \pm 0,6$ & III \\
\hline 93 & Чернозем типичный & 33 & 15 & $5,0 \times 3,0$ & $13,2 \pm 0,3$ & $10,2 \pm 0,4$ & III \\
\hline 109 & Чернозем типичный & 34 & 30 & $5,0 \times 3,0$ & $10,4 \pm 0,2$ & $8,0 \pm 0,1$ & III \\
\hline 102 & Серая лесная почва & 38 & 30 & $5,0 \times 1,5$ & $14,9 \pm 0,3$ & $13,0 \pm 0,2$ & III \\
\hline 104 & Чернозем типичный & 40 & 20 & $5,0 \times 1,5$ & $15,5 \pm 0,3$ & $15,0 \pm 0,2$ & III \\
\hline 105 & Чернозем типичный & 39 & 30 & $5,0 \times 1,5$ & $11,3 \pm 0,2$ & $13,2 \pm 0,3$ & II \\
\hline
\end{tabular}

рядовой посадкой. Встречаются лесополосы, в которых дуб высевался гнёздами с размещением $5 \times 3$ м, а в рядах высаживались сопутствующие породы. В насаждениях, созданных квадратногнездовым посевом, к возрасту 17-21 года дуб черешчатый достигал высоты 5,9-7,7 м, в то время как в лесополосах, созданных рядовой посадкой и с размещением посадочных мест 1,5 × 0,5 м эти показатели были ниже на 15,0-20,0 \% (табл. 5).

При этом в гнездовых посевах показатели средних диаметров выше на 28 \%, чем при рядовой посадке.

Однако при проведении рубок ухода показатели роста дуба в гнездовых посевах могут быть даже ниже, чем в рядовых.

При выращивании дуба гнездовым посевом сомкнутость полога находится в пределах 0,5-0,8; сомкнутость в рядах - 0,6-0,9, что приводит к сильному задернению почвы (злаковые растения). Ввиду высокой степени проективного покрытия травянистой растительностью происходит замедление роста древесных растений. В таких лесополосах не создаются условия для формирования лесной обстановки, толщина подстилки больше, чем в смешанных широких полосах. Однако она находится в сухом состоянии, её превращение в органическую массу замедляется.

Таблица 5

Рост дуба черешчатого в полезащитных полосах, созданных посевом и посадкой

\begin{tabular}{|c|c|c|c|c|c|c|c|}
\hline $\begin{array}{l}\text { № } \\
\text { пр. } \\
\text { пл. }\end{array}$ & Тип почвы & $\begin{array}{c}\text { Возраст, } \\
\text { лет }\end{array}$ & $\begin{array}{c}\text { Способ соз- } \\
\text { дания }\end{array}$ & $\begin{array}{c}\text { Размещение } \\
\text { посад. мест, м }\end{array}$ & $\begin{array}{l}\text { Сохран- } \\
\text { ность, \% }\end{array}$ & Высота, м & $\begin{array}{c}\text { Диаметр, } \\
\text { см }\end{array}$ \\
\hline 1 & $\begin{array}{c}\text { Чернозём } \\
\text { выщелоченный }\end{array}$ & 17 & Посев & $5,0 \times 3,0$ & 100 & 6,0 & 6,3 \\
\hline 2 & $\begin{array}{c}\text { Чернозём } \\
\text { выщелоченный }\end{array}$ & 17 & Посадка & $1,5 \times 0,5$ & 60,5 & 5,2 & 5,3 \\
\hline 3 & $\begin{array}{c}\text { Чернозём } \\
\text { выщелоченный }\end{array}$ & 17 & Посадка & $1,5 \times 0,5$ & 60,1 & 5,0 & 3,4 \\
\hline 4 & $\begin{array}{c}\text { Серые лесные } \\
\text { почвы }\end{array}$ & 17 & Посев & $5,0 \times 3,0$ & 100 & 5,9 & 6,6 \\
\hline 5 & $\begin{array}{c}\text { Серые лесные } \\
\text { почвы }\end{array}$ & 16 & Посев & $5,0 \times 3,0$ & 100 & 6,2 & 6,1 \\
\hline 6 & $\begin{array}{c}\text { Чернозём } \\
\text { выщелоченный }\end{array}$ & 22 & Посадка & $1,5 \times 0,5$ & 52,3 & 6,4 & 6,5 \\
\hline 7 & $\begin{array}{c}\text { Чернозём } \\
\text { выщелоченный }\end{array}$ & 21 & Посев & $5,0 \times 3,0$ & 99,1 & 7,7 & 8,3 \\
\hline
\end{tabular}




\section{Природопользование}

К возрасту 30-40 лет в чистых лесополосах из дуба, созданных квадратно-гнездовым посевом при ширине 15-30 м и без рубок ухода, формируется ажурно-продуваемая, ажурная, ажурно-непродуваемая, продуваемая структура, а в насаждениях с участием сопугствующих пород - плотная. В таких условиях показатели роста дуба черешчатого значительно меньше по отношению к показателям, созданным рядовой посадкой. Для формирования продуваемой структуры в лесополосах шириной более 15,0 м требуются значительные затраты на проведение рубок ухода.

В связи с тем, что дуб черешчатый плохо переносит пересадку, используется групповой посев желудей, одним из разновидностей которого является строчно-луночный посев, имеющий определенные преимущества по сравнению с гнездовым.

Большинство старовозрастных защитных насаждений с участием дуба имеют смешанный состав. В 40-60-е годы прошлого столетия защитные насаждения создавались из двух или нескольких древесных и кустарниковых видов шириной до 20,0-30,0 м. Способ, при котором дуб выращивают при участии сопутствующих и быстрорастущих пород, получил наименование коридорного. При коридорном способе улучшаются условия произрастания дуба, повышается влажность приземного слоя воздуха, уменьшается дефицит влаги в почве, улучшается освещаемость верхней части дубков прямым солнечным светом, увеличивается притененность средних частей деревьев и затенённость нижних [5].

Успешность роста дуба при выращивании в коридорах также зависит от ширины междурядий, энергии роста сопутствующих или быстрорастущих пород, изменения почвенных условий, числа рядов дуба, влияния видового состава кустарника и других спутников.

В лесных полосах в возрасте 30-36 лет при ширине междурядий 2,5 м таксационные показатели дуба выше, чем в насаждениях с шириной междурядий 1,5 м (средний диаметр больше на $24 \%$, высота - на $46 \%$ ).

Сравнение биометрических показателей роста лесополос в возрасте 39-45 лет (ширина междурядий 1,5 м) с показателями других насаждений, но с шириной междурядий 2,5 м свидетельствует о преимуществе более широких междурядий (различия составляют 20 \%). Аналогичные закономерности получены при сравнении показателей роста дуба черешчатого в возрасте 50-55 лет с шириной междурядий 1,5 и 2,5 м. Высоты дуба равны соответственно 20,8 и 23,7 м, бонитеты II и I в пользу более широкого междурядья.

Рост и состояние дуба зависят и от того, какие породы выращиваются в насаждениях совместно с ним. Соотношение в росте дуба и сопутствующих пород будет определяться их энергией роста, биохимическим взаимовлиянием и другими факторами.

Нами изучены лесополосы с участием дуба черешчатого, берёзы повислой, тополя бальзамического, клёна остролистного и татарского, ясеня обыкновенного и зелёного, вяза обыкновенного. В лесных полосах ясень обыкновенный оказывает на рост дуба более благоприятное воздействие, чем ясень зелёный. При этом дуб в лесополосах с ясенем обыкновенным перерастет в росте дуб в лесополосах с ясенем зелёным по высоте на 16,6 \%, по диаметру - на 10,6 \%. Следовательно, дуб черешчатый более предпочтительно выращивать совместно с ясенем обыкновенным при порядном смешении и ширине междурядий 2,5 м.

Высокие показатели роста дуб черешчатый в возрасте 22 лет имеет в лесополосах, где его чистые ряды чередуются с рядами клёна татарского, который в росте по высоте и диаметру отстает от дуба. При этом средний диаметр и средняя высота главной породы составляют 13,0 см и 11,6 м.

Наиболее высокие показатели роста дуб черешчатый имеет в смешении с клёном остролистным по отношению к насаждениям из чистых культур. В возрасте 38 и 40 лет средний диаметр дуба равен 14,9 и 15,5 см., средняя высота - 13,0 и 15,0 м, бонитет II и I. При совместном выращивании с клёном остролистным, ясенем зелёным и яблоней эти показатели соответственно равны 11,3 и 12,6 см, 9,8 и 1,2 м, бонитет - II.

В возрасте 36 лет при выращивании в коридорах из быстрорастущих пород дуб имеет более низкие показатели роста при порядном смешении и узком междурядье (1,5 м), где его рост оценивается по II классу бонитета, высота в 2 раза, а диаметр - в 1,9 раза ниже соответствующих показателей берёзы повислой. При этом данные показатели также ниже соответствующих показателей дуба в чистых лесополосах. Следовательно, при таком смешении и ширине междурядий выращивание дуба является нецелесообразным. 


\section{Природопользование}

Рост дуба черешчатого при выращивании в коридорах зависит также от числа рядов. В насаждениях, где дуб размещается несколькими рядами среди рядов из быстрорастущих пород, диаметр выше на $9 \%$, высота на 33 \% в сравнении с лесными полосами, где главная порода представлена одиночным размещением. Вышеизложенное позволяет сделать вывод о том, что для уменьшения влияния быстрорастущих пород необходимо увеличивать ширину междурядий или высаживать дуб в коридорах из быстрорастущих пород несколькими рядами, или отделяя ряды дуба от рядов быстрорастущей породы рядами сопугствующих пород (клён, липа и др.).

Менее значимые различия в росте дуб черешчатый имеет в лесополосах при порядном смешении с кустарниками. Это связано с отсутствием надлежащего подгона, в качестве которого обычно выступают сопугствующие породы, которые по энергии роста не превосходят дуб. Так, в возрасте 31 год в насаждениях, произрастающих в одинаковых условиях, при одинаковой густоте посадки, где ряды дуба чередуются с рядами акации жёлтой и подгонной породы, дуб черешчатый имеет большие высоту на $22,0 \%$, диаметр на $38,0 \%$ по отношению к насаждениям, где введена только акация жёлтая.

Полезащитная эффективность лесных полос определяется рядом показателей, в том числе площадью пашни, находящейся под защитой 1 га или 1 км лесополосы. В качестве факторов, от которых зависят эти показатели, выступают состав древесных пород, ширина, возраст, конструкция, высота защитного полога, дальность ветрозащитного влияния.

Наиболее высокие показатели полезащитной эффективности имеют лесополосы из дуба черешчатого при смешении с быстрорастущими породами, минимальной ширине, продуваемой структуры, максимальной для данных условий высоте. При рациональном размещении рядов дуба и рядов быстрорастущих и сопугствующих пород, оптимальной ширине полос и размещении посадочных мест, своевременном и качественном проведении рубок ухода в таких насаждениях можно формировать продуваемую структуру.

Смешанные полезащитные насаждения с участием дуба черешчатого, быстрорастущих и сопугствующих пород, в которых сформировалась плотная, ажурно-продуваемая структура, по эффективности уступают насаждениям продуваемой конструкции в 1,5-2,0 раза. Эффективность таких лесополос может быть повышена за счёт проведения рубок ухода и реконструкции.

\section{Выводы:}

1. Наилучшие показатели роста по высоте и диаметру дуб черешчатый имеет на типичном чернозёме и тёмно-серых лесных почвах, которые в наибольшей мере отвечают биологическим потребностям этой древесной породы.

2. Оптимальным размещением посадочных мест дуба черешчатого в рядовых полезащитных лесополос является $2,5 \times 0,7-1,0$ м с густотой посадки 4,06,0 тыс. шт./ га.

3. Наиболее оптимальной шириной лесных полос из дуба черешчатого является ширина 7,5-10,0 м, но не более $15,0 \mathrm{~m}$.

4. В смешанных защитных насаждениях наилучшими сопугствующими породами для дуба черешчатого являются клён остролистный, липа мелколистная, ясень обыкновенный, ясень зелёный, клён татарский. При этом целесообразно использовать порядное смешение дуба с сопутствующими породами.

5. Для повышения полезащитной эффективности лесных полос дуб черешчатый следует выращивать в коридорах из быстрорастущих пород. Расстояние между рядами дуба и быстрорастущих пород должно быть не менее 2,5 м, а при использовании ширококронных тополей - 3,0 м. Выращивать дуб в коридорах из быстрорастущих пород целесообразно несколькими рядами или отделять ряды дуба от рядов быстрорастущей породы рядами сопутствующих пород (клён, липа и др.).

6. Целесообразно выращивать дуб при порядном смешении с кустарником из-за отсутствия подгона, роль которого выполняют сопугствующие породы.

7. Наиболее высокие показатели полезащитной эффективности лесополосы из дуба черешчатого имеют при совместном его выращивании с быстрорастущими породами, минимальной ширине насаждения, формировании продуваемой конструкции, максимальной для данных условий высоте. Полезащитная эффективность лесных полос продуваемой структуры в 1,52,0 раза выше, чем у насаждения плотной, ажурной и ажурно-продуваемой структуры. 


\section{Природопользование}

\section{Библиографический список}

1. Агролесомелиорация [Текст] : моногр. / П. Н. Проездов [и др.]. - Саратов, 2016. - 474 с.

2. Волков, С. В. Рост дуба в полезащитных насаждениях различной ширины [Текст] / С. В. Волков, В. Н. Егоров, Ю. К. Трубицин // Бюллетень ВНИАЛМИ. - Волгоград, 1982. - Вып. 3 (39). - С. 15-16.

3. Кудряшов, Н. Н. Вариационная статистика [Текст] / Н. Н. Кудряшов. - Пенза, 2018. - 131 с.

4. Методические основы оценки лесогидромелиоративных систем [Текст] : учеб. пособие / В. К. Попов [и др.]. - Воронеж, 2005.- 79 с.

5. Михин, В. И. Особенности защитного лесоразведения с участием дуба черешчатого в условиях Центрального Черноземья [Текст] / В. И. Михин, П. В. Ковалёв, Е. А. Михина // Проблемы деградации дубрав и современные системы ведения лесного хозяйства в них : матер. науч.-практ. семинара, Воронеж, 28-30 марта 2007 г. - Воронеж, 2007. - С. 188-191.

6. ОСТ 56-69-83 Площадки пробные лесоустроительные, метод закладки [Текст]. - М. : ЦБНТИлесхоз, 1984. $-60 \mathrm{c}$.

7. Стаднюк, А. П. Рост полезащитных лесных полос из дуба черешчатого [Текст] / А. П. Стаднюк // Лесное хозяйство. - 1980. - № 7. - С. 37-39.

8. Effects of Governance on Availability of Land for Agriculture and Conservation in Brazil [Text] / G. Sparovek [ et al.] // Environmental Science and Technology. - 2015. - Vol. 49. - Issue 17. - pp. 10285-10293.

9. Forest restoration following surface mining disturbance: challenges and solutions [Text] / S. E. Macdodals [et al.] // New Forests. - 2015. - Vol. 46. - Iss. 5-6. - pp. 703-732.

10. Lewis, S. L. Increasing human dominance of tropical forests [Text] / S. L. Lewis, D. P. Edwards, D. Galbraith // Science. - 2015. - Vol. 349. - Issue 6250. - pp. 827-832.

\section{References}

1. Proezdov P. N. [et al.] Agrolesomelioraciya [Agroforestry]. Saratov, 2016, 474 p. (In Russian)

2. Volkov S. V., Egorov V. N., Trubicin Yu. K. Rost duba v polezashhitnykh nasazhdeniyakh razlichnoj shiriny [Growth of an oak in various types of width of shelter stands] VNIALMI Bulletin. Volgograd, 1982, Vol. 3 (39), pp. 1516. (In Russian)

3. Kudryashov N. N. Variacionnaya statistika. [Variational statistics] Penza, 2018, 131 p. (In Russian)

4. Popov V. K. [et al.] Metodicheskie osnovy ocenki lesogidromeliorativnykh sistem [Methodological basis for the assessment of forest hydromeliorative systems]. Voronezh, 2005, 79 p. (In Russian)

5. Mikhin V. I., Kovalyov P. V., Mikhina E. A. Osobennosti zashhitnogo lesorazvedeniya s uchastiem duba chereshchatogo $v$ usloviyakh Central'nogo Chernozem'ya [Features of protective afforestation with the participation of pedunculate oak in the conditions of the Central Black Earth Region] Problemy degradacii dubrav i sovremennye sistemy vedeniya lesnogo khozyajstva $v$ nikh : materialy nauchno-prakticheskogo seminara, [Problems of Deforestation and Modern Systems forest management in them: mater. scientific-practical seminar] Voronezh, 28-30 marta 2007, 2007, pp. 188-191. (In Russian)

6. OST 56-69-83 Ploshhadki probnye lesoustroitel'nye, metod zakladki. [OST 56-69-83 Pilot land management sites, bookmark method] Moscow, 1984, 60 p. (In Russian)

7. Stadnyuk A. P. Rost polezashhitnykh lesnykh polos iz duba chereshchatogo [The growth of forest shelter belts from pedunculate oak] Lesnoe hozyajstvo. [Forestry] 1980, no 7, pp. 37-39. (In Russian)

8. Sparovek G. [et al.] Effects of Governance on Availability of Land for Agriculture and Conservation in Brazil Environmental Science and Technology, 2015, Vol. 49, Issue 17, pp. 10285-10293.

9. Macdodals S. E. [et al.] Forest restoration following surface mining disturbance: challenges and solutions New Forests, 2015, V. 46, Iss. 5-6, pp. 703-732.

10. Lewis S. L., Edwards D.P., Galbraith D. Increasing human dominance of tropical forests Science,. 2015, Vol. 349, Issue 6250, pp. 827-832. 


\section{Природопользование}

\section{Сведения об авторах}

Михин Вячеслав Иванович - заведующий кафедрой лесных культур, селекции и лесомелиорации ФГБОУ ВО «Воронежский государственный лесотехнический университет имени Г.Ф. Морозова», доктор сельскохозяйственных наук, доцент, г. Воронеж, Российская Федерация; e-mail: lesomel@yandex.ru.

Михина Елена Александровна - доцент кафедры лесных культур, селекции и лесомелиорации ФГБОУ ВО «Воронежский государственный лесотехнический университет имени Г.Ф. Морозова», кандидат сельскохозяйственных наук, доцент, г. Воронеж, Российская Федерация; e-mail: lesomel@yandex.ru.

\section{Information about authors}

Mikhin Vyacheslav Ivanovich - Head of the Department of Forest Crops, Breeding and Forest Reclamation Federal State Budget Education Institution of Higher Education «Voronezh State University of Forestry and Technologies named after G.F. Morozov», DSc (Agriculture), Associate Professor, Voronezh, Russian Federation; e-mail: lesomel@yandex.ru.

Mihina Elena Alexandra - Associate Professor of the Department of Forest Crops, Breeding and Forest Reclamation Federal State Budget Education Institution of Higher Education «Voronezh State University of Forestry and Technologies named after G.F. Morozov», PhD (Agriculture), Associate Professor, Voronezh, Russian Federation; e-mail: lesomel@yandex.ru.

DOI: 10.12737/article_5c1a321a507285.66229007

УДК 630.2

\section{СРАВНИТЕЛЬНАЯ ХАРАКТЕРИСТИКА ПОЧВЕННЫХ УСЛОВИЙ ПОСТАГРОГЕННЫХ ЗЕМЕЛЬ И РАСТИТЕЛЬНОГО ПОКРОВА СЕВЕРНОГО ВЫЕТНАМА И СЕВЕРО-ЗАПАДА РОССИИ} Нгуен Тхи Тху Хыонг

доктор сельскохозяйственных наук, профессор Н. В. Беляева ${ }^{1}$

доктор сельскохозяйственных наук, профессор Д. А. Данилов ${ }^{2}$

1 - ФГБОУ ВО «Санкт-Петербургский государственный лесотехнический университет имени С.М. Кирова», г. Санкт-Петербург, Российская Федерация

2 - ФГБНУ Ленинградский НИИСХ «Белогорка», Ленинградская область, Российская Федерация

В работе изучены особенности возобновительных процессов растительности на землях, вышедших из хозяйственного оборота в условиях Северного Вьетнама, и на постагрогенных землях Ленинградской области. Рассматриваются ландшафтные особенности Национального парка Кук Фыонг и Ижорского плато. Различия в географическом положении регионов исследования позволяют выделять на контрастном фоне общие закономерности формирования растительного покрова на почвах, сформировавшихся на известняковых материнских породах. Анализируется состояние почв бывших земель сельскохозяйственного использования на карбонатных материнских породах в районах исследования в различных ландшафтных местоположениях. Отмечается высокий уровень плодородия на объектах исследования, сложившийся в результате предыдущего сельскохозяйственного использования данных земель. Проведено исследование видового состава растительности для рассматриваемых регионов. Отмечается, что видовое разнообразие растительных видов высокое, что связано с повышенным плодородием данных участков, сложившимся в результате предыдущего пользования и карбонатной материнской породы в регионах исследования. Сравнительный анализ процессов естественного возобновления на бывших сельскохозяйственных землях на известковых материнских породах показывает, что независимо от географического расположения на данных территориях происходит успешное возобновление аборигенными древесными породами. Данные участки постагрогенных земель являются местообитанием редких видов растительности для регионов исследования.

Ключевые слова: постагрогенные земли, ландшафты, карбонатные материнские породы, естественное возобновление, видовое разнообразие. 